Received $\quad 07.09 .2015$ Reviewed 14.10.2015 Accepted 23.11.2015

A - study design

B - data collection

C - statistical analysis

D - data interpretation

E - manuscript preparation

F - literature search

\title{
On bankfull methods determination again - why we care?
}

\author{
Artur RADECKI-PAWLIK ${ }^{1)}$ ADEF, Tomasz SKALSKI ${ }^{2)}$ ABEF, \\ Karol PLESIŃSKI $^{\text {3) }}{ }^{\mathrm{CE}}$, Wiktoria $\mathrm{CZECH}^{\text {3) } \mathrm{CE}}$
}

\footnotetext{
1) Faculty of Environmental Engineering and Land Surveying, University of Agriculture in Cracow, al. Mickiewicza 24/28, 30-059 Kraków, Poland; e-mail: rmradeck@cyf-kr.edu.pl

2) Department of Entomology, Institute of Zoology, Jagiellonian University, ul. Gronostajowa 9, 30-387 Kraków, Poland

${ }^{3)}$ Department of Hydraulics Engineering and Geotechnics, University of Agriculture in Cracow, al. Mickiewicza 24/28, 30-059 Kraków, Poland
}

For citation: Radecki-Pawlik A., Skalski T., Plesiński K., Czech W. 2015. On bankfull methods determination again - why we care? Journal of Water and Land Development. No. 27 p. 21-27.

\begin{abstract}
One more time we would like to pay attention of especially of the hydraulic engineer audience to bankfull stage and discharge. Along the paper we show commonly accepted definitions of it and ways of calculations. It is difficult to determine the size of the bankfull flow level, that is why the authors are presenting many selected methods. Some of the methods allow the determination of biotic bankfull flow through the occurrence of zones of vegetation characteristic and based on the observation of the occurrence of ground beetles (e.g. the Woodyer and the Radecki-Pawlik and Skalski methods). Some of the methods - most popular- are using morphometric parameters (e.g. the Williams, the Hey and Thorne, the Gauckler-Manning and finally the Lambor methods).

We believe that the value of bankfull discharge would be accepted as a supporting tool for designers, hydraulics engineers and managers, especially those who care about river channel environment and cooperate with fluvial geomorphologists- and biologists as well as environmental agencies.
\end{abstract}

Key words: bankfull, river, river bank, stream

\section{INTRODUCTION}

A commonly accepted and universally applicable definition of bankfull was provided by DUNNE and LEOPOLD [1978] where the bankfull stage corresponds to the discharge at which channel maintenance is the most effective. Thus we are thinking about the discharge at which sediment is moving, river bars are formed and generally doing work results in the average morphologic characteristics of channels [EPA 2015]. Following that we would like to add the opinion of CHURCH [2015] that the duration of inundation and the season in which it occurs may significantly condition the channel edge and riparian zones. Thus significant correlations have been demonstrated be- tween plant communities and elevation above normal water levels, hence usual duration of inundation (e.g., WOODYER [1968]) and between certain invertebrates and elevation (e.g., RADECKI-PAWLIK, SKALSKI $[2008 \mathrm{a}, \mathrm{b}])$. The term bankfull was originally used to describe the incipient elevation on the bank where flooding begins. In many stream systems, the bankfull stage is associated with the flow that just fills the channel to the top of its banks and at a point where the water begins to overflow onto a floodplain [EPA 2015].

In regulated streams determination of bankfull or channel-forming flow depth may be difficult or inaccurate. As it is said in National Management Measures to Control Nonpoint Source Pollution from Hy- 
dromodification by [EPA 2015], changes created by channelization and channel modification activities are problematic because they unexpectedly alter environmental parameters to levels outside normal or desired ranges. The physical and chemical characteristics of surface waters that may be influenced by channelization and channel modification include sedimentation, turbidity, salinity, temperature, nutrients, dissolved oxygen, oxygen demand, and contaminants. Thus we are not supposed to relay on bankfull results obtained from regulated streams using described here in the paper bankfull determination methods.

In the present paper we are interested in bankfull since is often invoked as the most effective flow (where effective flow may be defined as that discharge which transports most bed sediment in a stream that is close to steady-state conditions).because this represents the maximum flow that occurs within the confines of the channel, hence exerts the largest stresses on the channel boundaries, whilst rarer overbank flows have negligibly more severe effect within the channel [CHURCH 2015]. Because of that it could be treated to some point as a channel forming discharge, helping to understand river channel forming processes in fluvial sciences and find the appropriate river bank (Photo 1). But the concepts of bankfull and dominant discharges are useful not only for scientists but first of all for practitioners, designers and engineers from river/stream management while working in the designing office for establishing, for example, dimensions of engineering structures [RADECKI-PAWLIK 2015]. Thus along that paper we again try to summarize up some knowledge about bankfull and get acquainted especially Polish engineers and designers with it. For those who care for river environment and Polish waters which one day we can have not enough for all when running water management policy as well as allow for many who in the wrong way design hydraulic structures projects as we do at the moment, which are done by so called professional designers-pretenders with no experience in the field but taking their experience from the computer screen.
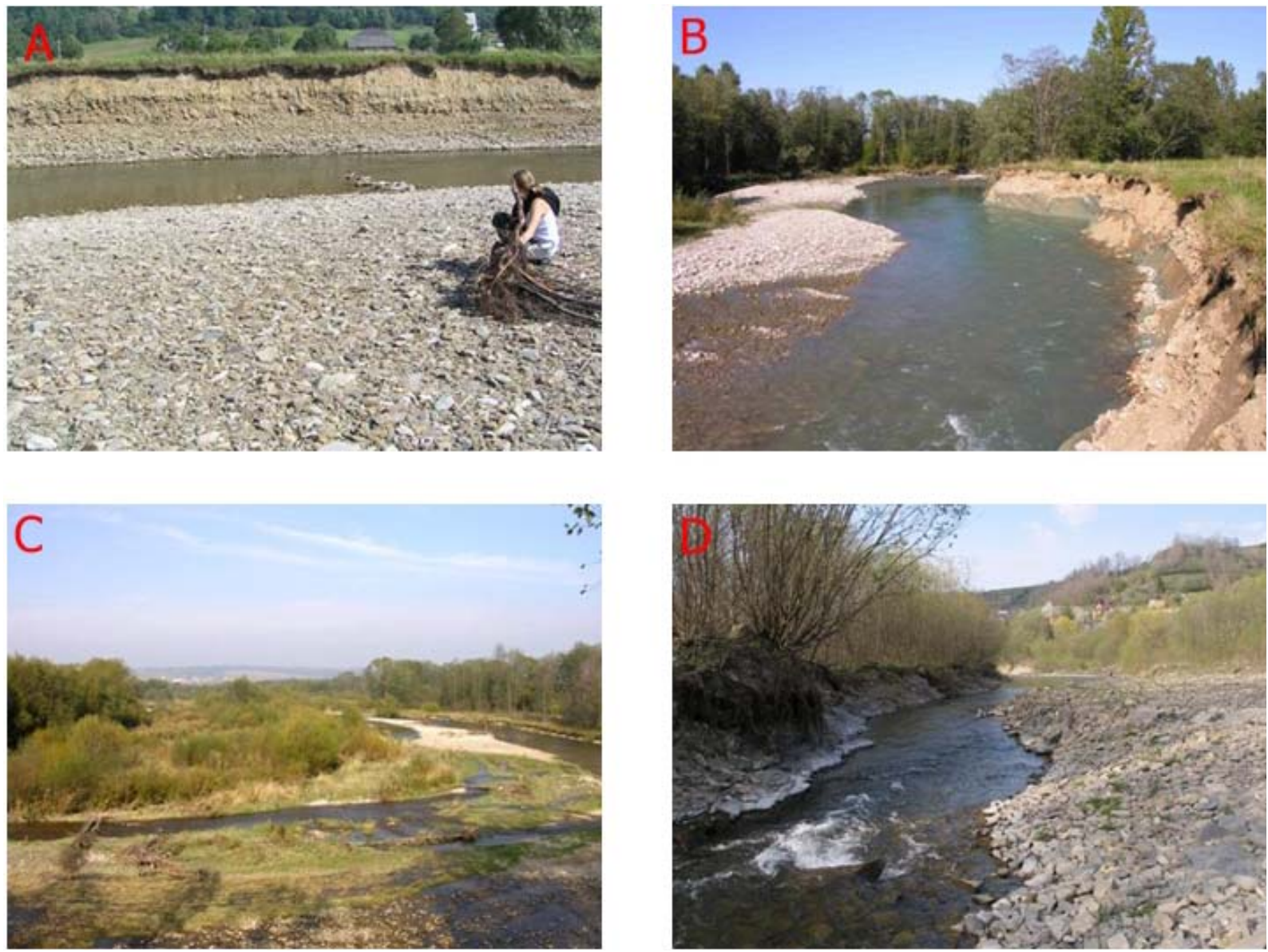

Photo $1 . \mathrm{A}$ - where is a river bank? - when determining bankfull, usually not the bankfull value determination method is a problem but chosen an appropriate level of a river bank, the Wisłok River (Poland); B - hard to decide where is a river bank for one thread channel, the Czarny Dunajec River (Poland); C - difficult choice on the river bank line for multithread channel, the Czarny Dunajec River (Poland); D - difficult choice on the river bank line for a single thread channel, Porębianka stream (Poland) (phot. A. Radecki-Pawlik) 


\section{BANKFULL DETERMINATION METHODS}

Below we are describing a few most popular methods when using them one can determinate bankfull. Some of them were already used for Polish streams and rivers (look up the relevant papers).

\section{LAMBOR METHOD}

According to LAMBOR [1971] $Q_{b}$ flow should be defined as a flow of water occurs between the state average annual and the average big. To determine the flow rate is needed flow volume curve and flow frequency curve.

According to the author it is the state of water flow occurring between the stamen and the average annual average flow is called a big edge. According to LAMBOR [1971] bankfull discharge has a very significant influence on the water course beds [ŁAPUSZEK, LENAR-MATYAS 2013].

\section{GAUCKLER-MANNING METHOD}

Gauckler and Manning [CHOw 1959] describe bankfull discharge as a simple volume of water. So their theory is based on a formula which allows calculating directly the wanted discharge:

$$
Q_{b}=\frac{1}{n} A_{b} \cdot D_{b}^{\frac{2}{3}} \cdot S^{\frac{1}{2}}
$$

where:

$Q_{b}=$ the bankfull discharge, $\mathrm{m}^{3} \cdot \mathrm{s}^{-1} ;$

$A_{b}=$ the water area when its bankfull discharge, $\mathrm{m}^{2}$;

$D_{b}=$ the depth at bankfull, m;

$S=$ is the slope of the river;

$n=$ the roughness coefficient.

However, this formula needs to primary determine geometric properties - water area and water depth - using another method: field determination by observing, or first steps of WOLMAN [1955] method for example.

\section{WILLIAMS METHOD}

WiLliams [1978] method was developed from the Gauckler-Manning formula which is the following equation:

$$
Q_{b}=4.0 A_{b}^{1.21} S^{0.28}
$$

He discovered his formula working on 51 streams and rivers. According to many this method works well in places with no gauging station data available.

\section{HEY AND THORNE METHOD}

Hey and Thorne method, well-known as Hey and Thorne's equations [THORNE et al. 1997] consists several equations which allow to calculate many geomorphological characteristics of the river (meander arc length, sinuosity, pool and riffles) according the vegetation type.

However, what are important for this study are the two following equations with which bankfull discharge was determinated in the research areas:

Bankfull mean depth:

$d=0.22 Q^{0.37} D_{50}{ }^{-0.11}(\mathrm{~m})$

Bankfull maximum depth:

$d_{m}=0.20 Q^{0.36} D_{50}{ }^{-0.56} D_{84}{ }^{0.35}(\mathrm{~m})$

In both equations we need some information about grain-size characteristics of bed sediments: $D_{50}$ and $D_{84}$ - which are taken from the grain-size curve. Then, it consists in calculating these depths for a chosen scale of discharges and looks the correspondence between discharge and depths.

\section{RADECKI-PAWLIK AND SKALSKI METHOD}

Another method of bankfull determination is provided by RADECKI-PAWLIK and SKALSKI [2008a, b]. The method is biological and is based on an index of Invertebrate Bankfull Assessment (IBA). This index is related to the term body length macro invertebrate animals, Coleoptera: Carabidae [SKALSKI et al. 2012], see photo 2 .

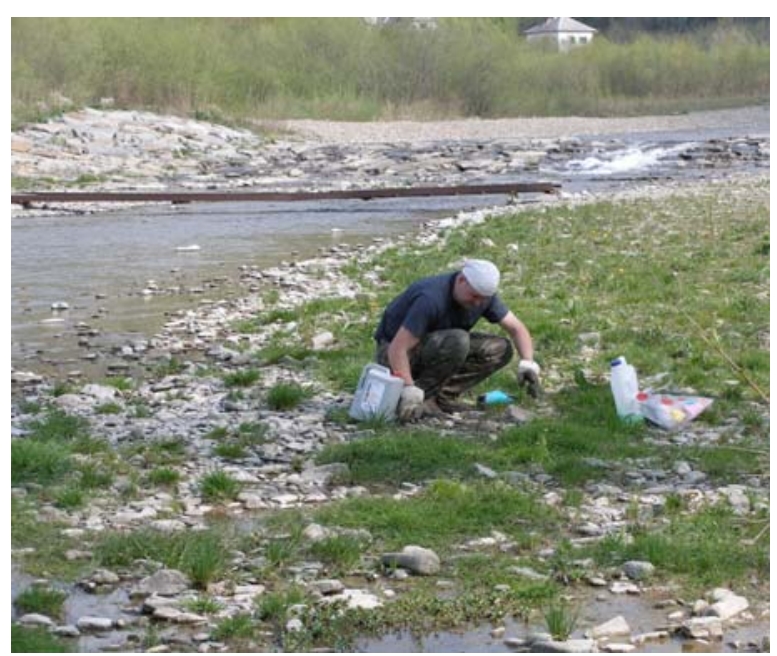

Photo 2. Instalation of barber traps (ground bittle traps) for RADECKI-PAWLIK and SKALSKI [2008a, b] method, Porębianka stream - Poland (phot. A. Radecki-Pawlik)

Method called IBA method based on the identification of certain species of invertebrate immune to the specific conditions of water flow in the river. Studies have shown that the average body length of beetles is the smallest for the first floodplain (little stable) and for subsequent coastal rarely flooded by water (covered with forest, meadow) studied individuals increased energy expenditure, which resulted in an increase in body size. Therefore the IBA index RADECKI-PAWLIK and SKALSKI [2008b] can be written as: 
$I B A=$ number of individuals with the size of $1-6 \mathrm{~mm}$ / number of individuals of $18-24 \mathrm{~mm}$ in size

When one use that relation it appears that the high terraces has got $I B A<1$, the middle $I B A$ terraces $\geq 1$ while the low terraces $I B A \gg>1$.

The method due to its simplicity (you only need to collect macroinvertebrates indicator and measure their body length). It is, at what rate the bank of live beetles tolerant or non-tolerant flood water (pulse dis- turbance) - Fig. 2, allows you to specify the value of the flow boundary at the food availability line - Fig. 3 [RADECKI-PAWLIK, SKALSKI 2008a, b].

The data cross-sections, designated subjectively made observations of biotic indices. In determining the types of terraces should be aware of the photographic documentation of plants, and collecting and drying their inflorescences, which occur in late spring [ŁAPUSZEK, LENAR-MATYAS 2013].

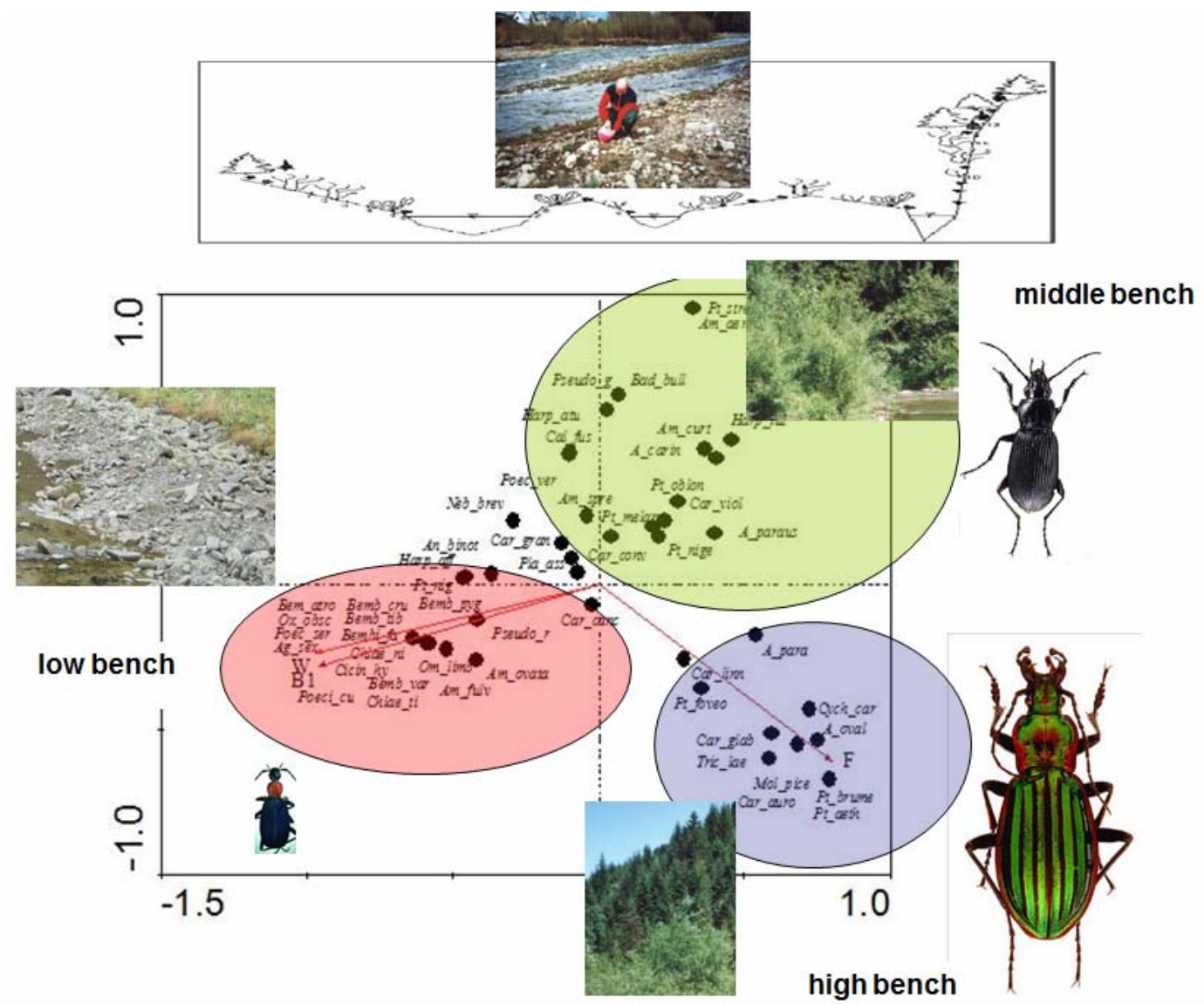

Fig. 1. Classification tree of ground beetles assemblages according to TWINSPAN analysis with respect to the characteristic habitats. Photograph corresponds to specific Woodyer benches, high, average and low respectively; source: RADECKI-PAWLIK, SKALSKI [2008a] modified

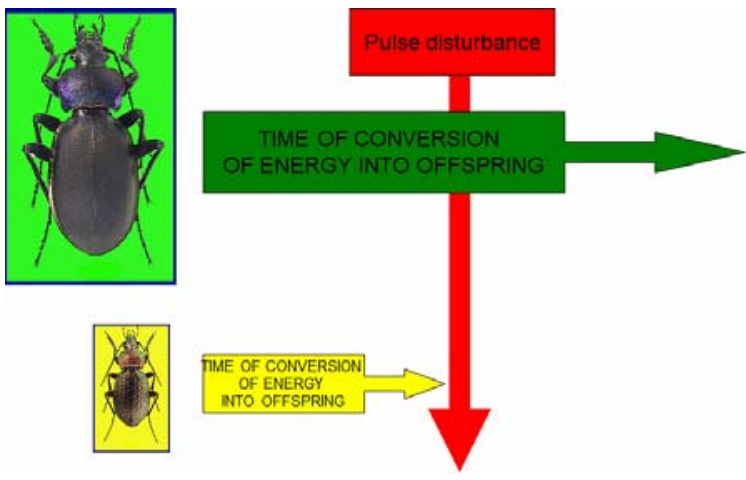

Fig. 2. Fitness - reproductive power, the rate of conversion of energy into offspring; source: own elaboration

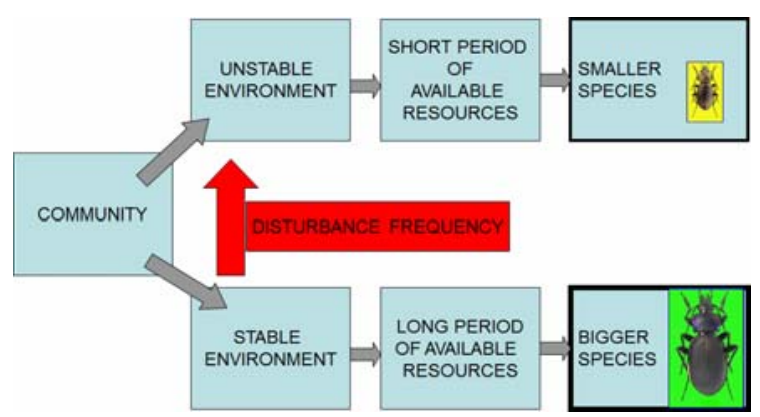

Fig. 3. Available resources and dimensions of species; source: own elaboration 


\section{WOODYER METHOD}

WOODYER [1968] described three types of elevation at the edge of the trough (high elevation, elevation average and elevation low) - Fig. 4. The first two are covered with characteristic plant species, whereas low elevation characterized by a lack of vegetation, or it may cover lichens (in periods of drought), or a thin layer of grass. Low area is covered with sediment trough such as sand, gravel and boulders. Often this zone, due to the confusing/problematic its designation is ignored when determining the full flow through [WOODYER 1968].

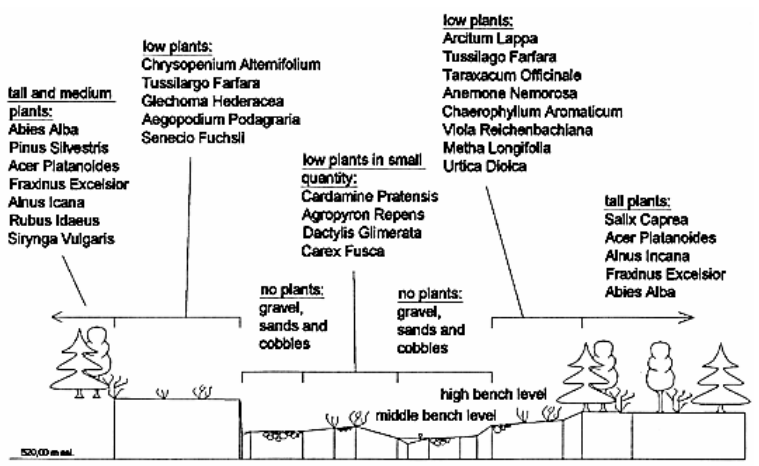

Fig. 4. The example sketch for WoODYer [1968] method of bankfull determination from the Skawica River cross-section; source: own elaboration

Average elevation vegetation is characterized by well-educated about the characteristics of wetlands land. To the flora of the greater demand for water include grasses and shrubs that respond well to periodic flood waters of the lagoons. Water shoreline is fixed to the level of high elevation. High shore colonized by trees and vegetation specifically developed high. Most frequently high bench is the widest and includes floodplains.

\section{LEOPOLD METHOD}

Research conducted by LEOPOLD [1994] allowed to conclude that the bankfull discharge has an average return interval of 1.5 years or $66.7 \%$ annual exceedance probability [DUNNE, LEOPOLD 1978; LEOPOLD 2005].

\section{WOLMAN METHOD}

WOLMAN [1955] suggested the method called the minimum form ratio. This method is based on the minimum channel width compared to its depth.

This theory has been assigned as correct, but only for square and rectangular trays [RILEY 1972].

To determine the bankfull width of the cross section should be compared to its depth (Fig. 5). At the plotted curve can be seen the collapse, which shows considerable width of the cross section and it is this point indicates bankfull flow. WOLMAN [1995] found

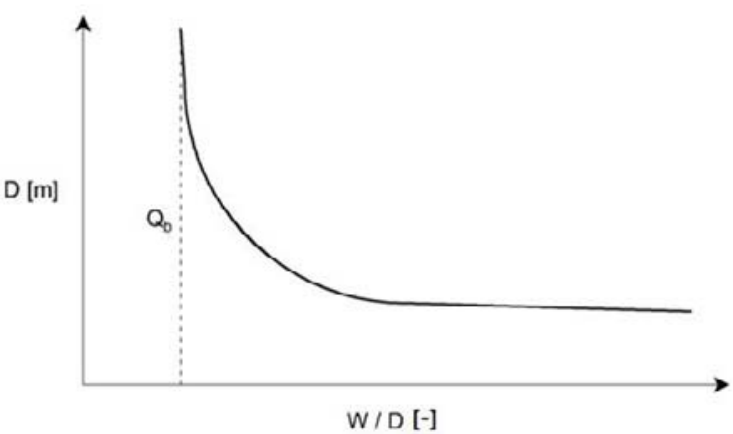

Fig. 5. Sketch of Wolman method; the graph showing he relationship between numerical sequence $W / D$ to a water depth $D(\mathrm{~m})$; source: own elaboration

that during the flow boundary average speed decreases, while the depth and slope of the increase. Wolman determines the flow of boundary occurs every 2.0 to 2.7 years.

The fact that flooding of the flood plain occurs periodically indicates that the flood-plain height is closely related to the regime of the stream which traverses the flood plain [WOLMAN 1955].

The formula for the numerical sequence is stored in the form of:

$$
R_{W}=\frac{W_{i}}{D_{i}} \quad i=1,2,3, \ldots, n-1
$$

where:

$R_{W}=$ numerical sequence $(-)$,

$W_{i} \quad=$ the width of channel at that depth, m;

$D_{i} \quad=$ water depth, $\mathrm{m}$.

Bankfull value is determined by over $R_{W}$, which consists of the ratio of the width of the streambed $W_{i}$ to a depth $D_{i}$. When the string value reaches a minimum value $R_{W}$, bankfull flow is determined.

\section{RILEY METHOD}

Proposed by RILEY [1972] method to determine the flow of the boundary based on the analysis of changes in the hydraulic radius $(\mathrm{Rh})$ and terraced in$\operatorname{dex}(B I)$.

Floodplain Channel Floodplain

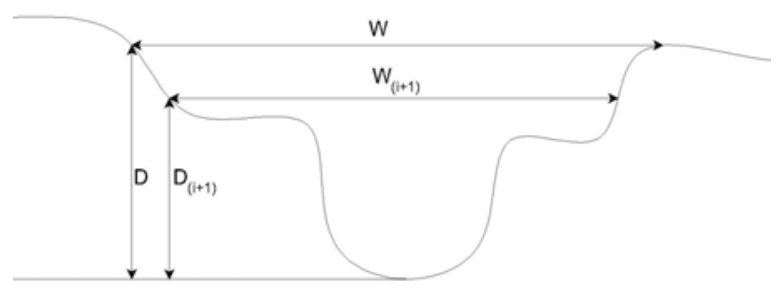

Fig. 6. The scheme of Riley method. Diagram shows the depth and the corresponding width of the riverbed along in increments of progression; source: own elaboration 


$$
B I=\frac{W_{i}-W_{i+1}}{D_{i}-D_{i+1}} \quad i=1,2,3, \ldots, n-1
$$

were:

$B I \quad=$ index value terraced Riley, - ;

$W_{i} \quad=$ width of the water level when filling $D_{i}, \mathrm{~m}$;

$D_{i} \quad=$ water depth at a certain level, $\mathrm{m}$;

$W_{i+1}=$ width of the channel at a depth, less the value adopted as jump over, $\mathrm{m}$;

$D_{i+1}=$ water depth less the value of the jump, m.

On the basis of the above formula is calculated over the subsequent values. The first obtained the maximum BI is the value of the flow boundary - Fig. 4. In addition, the method allows to calculate the local maxima, if needed [RADECKI-PAWLIK 2002].

Proposed by RILEY [1972] designation of the amount of water coastline is quite accurate for trapezoidal cross-section, with a mild slope edges. Additionally helpful in the calculation can be knowledge of the border vegetation high [RADECKI-PAWLIK 2002].

\section{RECAPITULATION}

The paper presented here shows some chosen methods of bankfull discharge determination. In the case of mountain rivers and streams bankfull discharge fills a stable alluvial channel to the elevation of the active floodplain. It is difficult to determine the size of the bankfull flow level, which is why the authors are presenting many selected methods. Some of the methods allow the determination of biotic bankfull flow through the occurrence of zones of vegetation characteristic and based on the observation of the occurrence of ground beetles. Note that the biotic methods determine the flow rate, but they are only aids in determining appropriate bankfull flow [RADECKI-PAWLIK, SKALSKI 2008a, b; SKALSKI et al. 2012; WOODYER 1968]. Some of the methods - most popular - are using morphometric parameters. For example - widely spread in the literature methods are based on the formula Gauckler-Manning, binding parameters of geometric cross-section of the trough, the decline in the water table and the roughness coefficient. When setting the flow rate $Q_{b}$ sections of mountain rivers, should remember that the flow rate should be fitted in the range of flows, and not only in one flow value [ŁAPUSZEK, LENAR-MATYAS 2013]. But all methods are supposed to help at work designers and managers, especially those who care about river channel environment and cooperate with geographers and biologists as well as environmental agencies.

\section{REFERENCES}

CHOw V.T. 1959. Open channel hydraulics. New York. McGraw-Hill pp. 680.

Church M. 2015. Channel stability: morphodynamics and the morphology of rivers. In: Rivers - physical, fluvial and environmental processes. Eds. P. Rowiński, A. Radecki-Pawlik. Springer, GeoPlanet: Earth and Planetary Sciences, Switzerland. p. 281-321.

DunNe T., LEOPOLD L.B. 1978. Water in environmental planning. San Francisco. W.H. Freeman. ISBN 0716700-79-4 pp. 818.

EPA 2015. Hydrologic processes: bankfull discharge [online]. [Access 07.09.2015]. Available at: http://water. epa.gov/contactus.cfm, http://water.epa.gov/scitech/ datait/ tools/warsss/bankfull.cfm

LAMBOR J. 1971. Hydrologia inżynierska [Hydrology for engineers]. Warszawa. PWN pp. 363.

LEOPOLD L.B. 2005. A view of the river. Harvard University Press pp. 298.

ŁAPUSZEK M., LENAR-MATYAS A. 2013. Utrzymanie i zagospodarowanie rzek górskich [River training and maintance]. Kraków. Wydaw. PK. ISBN 978-83-72427-28-1 pp. 283.

RADECKI-PAWLIK A. 2002. Bankfull discharge in mountain streams: theory and practice. Earth Surface Processes and Landforms. Vol. 27. Iss. 2 p. 115-123.

RADECKI-PAWLIK A. 2015. Why do we need bankfull and dominant discharges. In: Rivers - physical, fluvial and environmental processes. Eds. P. Rowiński, A. RadeckiPawlik. Springer, GeoPlanet: Earth and Planetary Sciences, Switzerland p. 497-519.

RADECKI-PAWLIK A., SKALSKI T. 2008a. A new concept to determinate bankfull discharge using invertebrate communities - an example from the Ochotnica stream, Polish Carpathians. Electronic Journal of Polish Agricultural Universities. Vol. 11. Part. 1 p. 1-13.

RADECKI-PAWLIK A., SKALSKI T. 2008b. Bankfull discharge determination using the new invertebrate bankfull assessment method. Journal of Water and Land Development. No. 12 p. $145-154$.

RILEY S.J. 1972. A comparison of morphometric measures of bankfull. Journal of Hydrology. Vol. 17. Iss. 1 p. 2331 .

SKALSKI T., KĘDZIOR R., RADECKI-PAWLIK A. 2012. Riverine ground beetles as indicators of inundation frequency of mountain stream: a case study of the Ochotnica Stream, Southern Poland. Baltic Journal of Coleopterology. Vol. 12. Iss. 2 p. 117-126.

WiLliams P.G. 1978. Bankfull discharge of rivers. Water Resources Research. Vol. 14. Iss. 6 p. 1141-1154.

Wolman M.G. 1955. The natural channel of Brandywine Creek, Pennsylvania. Geological Survey Professional Paper. 271 pp. 56.

WOODYER K.D. 1968. Bankfull frequency in rivers. Journal of Hydrology. Vol. 6 p. 114-142.

ThORNE C.R., HeY R.D., Newson M.D. 1997. Applied fluvial geomorphology for river engineering and management. Wiley. ISBN 978-0-471-96968-6 pp. 388. 


\section{Artur RADECKI-PAWLIK, Tomasz SKALSKI, Karol PLESIŃSKI, Wiktoria CZECH}

O metodach wyznaczania przepływu brzegowego -

dlaczego są tak ważne w obliczeniach inżynierskich?

\section{STRESZCZENIE}

Słowa kluczowe: brzeg rzeki, potok, przeptyw brzegowy, rzeka, strumień

W artykule zwraca się uwage, szczególnie inżynierów hydrotechników oraz meliorantów, na znaczenie znajomości wielkości przepływu brzegowego. Przedstawiono kilka najbardziej znanych metod obliczania tego przepływu i opisano, w jaki sposób zgromadzić dane do jego obliczenia. Cała trudność w obliczeniu przepływu brzegowego nie polega na skomplikowanych metodach obliczeń, lecz na określeniu miejsca, gdzie znajduje się istotnie brzeg rzeki lub potoku. Niektóre z metod umożliwiają określenie przepływu brzegowego na podstawie obserwacji biologicznych, przykładowo poprzez znalezienie stref charakterystycznej roślinności. Inne metody przyrodnicze bazują na obserwacji występowania biegaczowatych (metody: Woodyera i Radeckiego-Pawlik oraz Skalskiego). W większości metod korzysta się z określenia parametrów morfometrycznych (metody: Williamsa, Heya i Thorne'a, Gauckler-Manninga i Lambora).

Autorzy uważają, że metodyka obliczenia przepływu brzegowego jest ważna w interpretacji danych hydrologicznych, szczególnie przez inżynierów hydrotechników, do wyznaczaniu przepływów miarodajnych, gdzie byłaby narzędziem pomocniczym. 